Research Article

Open Access

Tatiana Vladimirovna Bogdanova, Elena Ermolaeva*

\title{
Acomparative Study of Psychological Characteristics of Teachers in Riga and Smolensk
}

DOI 10.1515/sigtem-2016-0010

\begin{abstract}
The paper presents results of research on priority values in teaching process, the psycho-emotional state, self-evaluation, style of teaching and the level of subjective control of contemporary Russian and Latvian schoolteachers. According to Rezapkina (Резапкина, 1999), these five categories form the psychological portrait of a teacher. The authors analyse and compare the numerical representations of these characteristics, their variations and correlations for the three groups of teachers of both countries, which differ by length of service. An attempt was made to identify some negative trends in professional identity of schoolteachers, which are common to the professional communities of Latvia and Russia.
\end{abstract}

Keywords: contemporary schoolteacher, psychological portrait of a teacher, priority values in teaching process, style of teaching, psycho-emotional state, self-evaluation, locus of control.

\section{Introduction}

Nowadays, when the education system is constantly being reformed, the most often discussed topics are the content and standards of education, methods of teaching, forms of evaluation of learning process results, the moral education of students, and so on. Less attention is paid to the teacher's personality, for example, to her/his emotional state in the modern educational environment, selfevaluation and priority values. This theme, as well as the more general theme of professional identity of teachers, has not been developed well enough in pedagogical research. However, the psychological state of schoolteacher is of great importance for both the teacher and society. This is connected with the role of pedagogical activity in the development of each person and the whole society, as well as with high intellectual, emotional, volitional and moral demands required by the teaching profession.

To study the psychological portrait of the contemporary schoolteacher, the Centre for Educational Research of Riga Teacher Training and Educational Management Academy together with Department of Psychology of Smolensk State University in March-April 2014 organised a survey of Riga and Smolensk teachers. They were asked to answer the questionnaire 'Psychological Portrait of a Teacher' developed by G.V. Rezapkina. Fifty test questions allowed the identification of priority values, emotional state, self-evaluation, teaching style and the level of subjective control of a teacher (Резапкина, 1999). The obtained results made it possible to analyse and compare the professionally important personality features of modern Latvian and Russian teachers, as well as to find out the difference between the answers of teachers with different work experience. In Latvia, the study was carried out within the framework of the Riga Teacher Training and Educational Management Academy (RTTEMA) research project Nr. 2014/7 'Professional identity of school and higher school teachers'.

*Corresponding author: Elena Ermolaeva, Riga Teacher Training and Educational Management Academy, Latvia Tatiana Vladimirovna Bogdanova, Smolensk State University, Russia 


\section{The Aim of the Study}

The aim of the study is to define and analyse parameters of the psychological portrait of modern schoolteachers according to five criteria (priority values, emotional state, self-evaluation, teaching style and the level of subjective control), as well as to compare the results of groups of teachers from both countries and with different lengths of service.

\section{Materials and Methods}

Testing was anonymous. The survey involved 400 teachers from 29 schools in Smolensk and 201 teachers from 11 schools of Riga, consisting in all of 601 respondents. Twenty-four questionnaires were not filled in correctly and therefore were not considered in the further process. The survey participants in each country were divided into three groups according to their experience in teaching: those who have worked in school not more than 5 years ( 96 people in Smolensk and 56 in Riga), those with length of service from 6 to 15 years (respectively, 85 and 52) and those with longer work experience (195 and 93).

The samples are representative by age and length of service both for Russian teachers and their Latvian colleagues (Priževoite, 2013; Geske, Ozola, 2014; Капржак, 2014; Малинецкий, Равлюк, Степанцов, 2005; Степанцов, 2005). In Riga as well as in Smolensk, the number of respondents with work experience more than 16 years was approximately equal to the total number of teachers in the other two groups. In both countries, the educational community is getting older.

In each of 50 items of the Rezapkina's questionnaire, a respondent had to choose one of three variants of the answer, depending on differences in his or her priority values in the teaching process, emotional state, self-evaluation, teaching style and the level of subjective control. As a result, each of these five categories was represented by three options measured by a score from 0 to 10 (Резапкина, 1999). During data processing, the mean rates (on the scale from 1 to 10), dispersion, standard deviation, coefficient of variation and statistical mode were calculated for each of the three options in every category, and for all groups of respondents.

The questionnaire made it possible to track the ranking of the following priority values in teaching: the relationship with children, the relationship with colleagues or own experiences. A brief description of these options is given below.

Focus on children. A teacher focuses on the child's interests and recognises the development of his or her personality as the main aim of teaching. A teacher is careful about the emotional life of a pupil and considers himself or herself equally responsible with the parents for the results of training and education.

Focus on colleagues. It is very important for a teacher to have comfortable, conflict-free relationship with colleagues; he/she gives great credence to opinions of colleagues (up to conformity and social dependence).

Own experiences. A teacher focuses on his/her own problems and experiences, to some extent disengages himself/herself from professional activities and feels alienated when communicating with students and colleagues.

Emotional state was defined as unfavourable, unstable or safe.

Unfavourable emotional state. Strong negative reaction to frustrating factors, low emotional stability, anxiety, reduction of intellectual capacities and affiliate aspirations decrease of the need for self-actualisation.

Unstable emotional state. Mood swings, lack of volitional regulation of the emotional sphere and lack of distinct affective attitudes. The distribution of responses corresponding to this option has a high dispersion; respondents often choose the situational answer ('It depends on the situation'), or the answer that shows reduced predictability of their own reactions ('I do not know').

Safe emotional state. Emotional stability, optimism, well-formed emotional patterns in the professional sphere.

Self-evaluation was defined as positive, unstable or negative.

Positive self-evaluation. Positive self-perception, as a result of person's activity, friendliness and openness in interrelation; teacher believes in his/her own ability to overcome difficulties. 
Unstable self-evaluation. Self-evaluation depends on the situation. There is an emotional and creative rise in a situation of success, but an unfavourable situation causes decrease of energy, expectation of assistance and dependence on public opinion.

Negative self-evaluation. Negative self-concept, self-doubt, vulnerability in communication, painful perception of criticism.

Teaching style was defined as democratic, liberal or authoritarian.

Democratic teaching style. A teacher listens to students, involves them into making decisions, encourages their independence and takes into account not only the performance but also the personal qualities of students. The main methods of influence on students are motivation, advice, request; the interrelation with students is friendly and respectful.

Liberal teaching style. A teacher is indecisive and inconsistent; he/she avoids responsibility and solution of problems leaving this to students, their parents, colleagues and the headmaster. There is no system in organising and control of activities of students. The interrelation with students is friendly, but passive and alienated; basic methods of influence are request and delegation of his/her authority to someone else.

Authoritarian teaching style. The relationship with others is dictatorial, any initiative is suppressed, discipline and subordination are of the most importance. The main methods of influence are the order and precept; the teacher uses his/her rights regardless of situation and opinions of others, but focuses on his own experiences and capabilities. Variability of behaviour is low.

Level of subjective control is subdivided into high, unformed, and low.

High level. High searching activity, independence of judgment, nonconformity and recognition of responsibility for personal life and actions.

Unformed level. Not fully developed responsibility for the relationship with others and for the circumstances of personal life; sparing situational assessment of teacher's own actions.

Low level. Inclination to explain events of personal life by social environment and coincidence of circumstances. Reduced responsibility for the results of teacher's own actions, social dependence.

\section{Results}

The highest statistical reliability and coherence for all groups of respondents in both countries have been observed for the second (emotional state) and fourth (teaching style) criteria.

\section{Teaching style}

Both in Russia and in Latvia, all three groups of teachers prefer the democratic style of teaching. In Smolensk, its mean rate is two to three times higher than that of the liberal and authoritarian styles; in Riga, it is three to four times higher (see Figs. 1 and 2; hereinafter all charts show the mean rates on the scale from 1 to 10 for the corresponding groups of respondents). In all three age groups of Smolensk teachers, the liberal and authoritarian styles have similar ratings. At the same time, the deviations from the democratic style occur more often in favour of dominance and authoritarianism (an excess of the mean score of the liberal style over the authoritarian one in the third group of teachers from Riga is statistically insignificant). In Russian schools, this can be explained by historical heritage, traditions of discipline and hierarchy relations. Some traces of the Soviet authoritarianism can still be felt in the schools of Latvia, too (although less than in Russia).

On the whole, mean rates of the democratic style in Riga are higher than those in Smolensk. Correspondingly, the mean scores for the liberal and authoritarian styles are slightly lower. The most significant difference of Riga from Smolensk was noted in the younger group of Riga's teachers. This is not surprising in view of the comparative research of values, attitudes and behaviors of Moscow and Riga high school students made in 2010-2011 by RTTEMA and the Institute of Sociology of Russian Academy of Education. The researchers carried out a survey that involved about 3000 pupils: students of the Moscow schools, Riga's students from schools where the language of instruction is Latvian and Rigans from schools with the Russian language of 
instruction (about 1000 people in each group). One of the aspects of the research concerned the identification of dialogicality / non-dialogicality in attitude and behaviour of young people in Moscow and Riga. Compared with the Moscow students, the Latvian respondents proved to be more dialogical and inclined to resolve conflict situations by more democratic methods (Jermolajeva, 2011). Riga's young teachers, who participate in the present research, belong to the same generation as the participants of the survey in 2010.

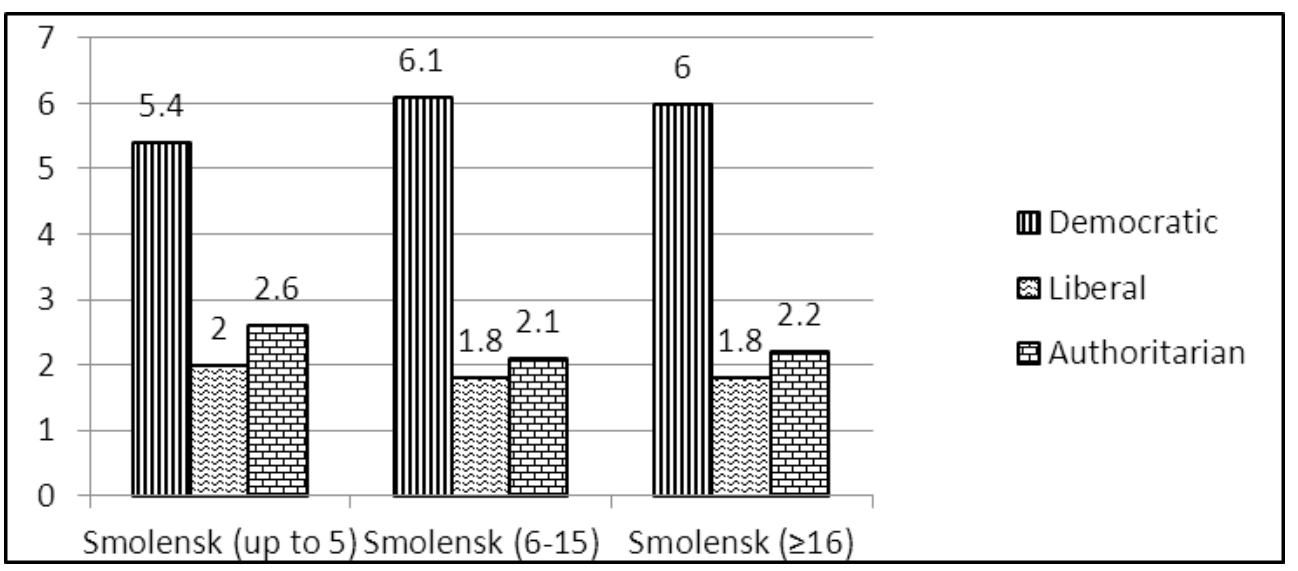

Fig. 1. Teaching style (mean rates). Smolensk

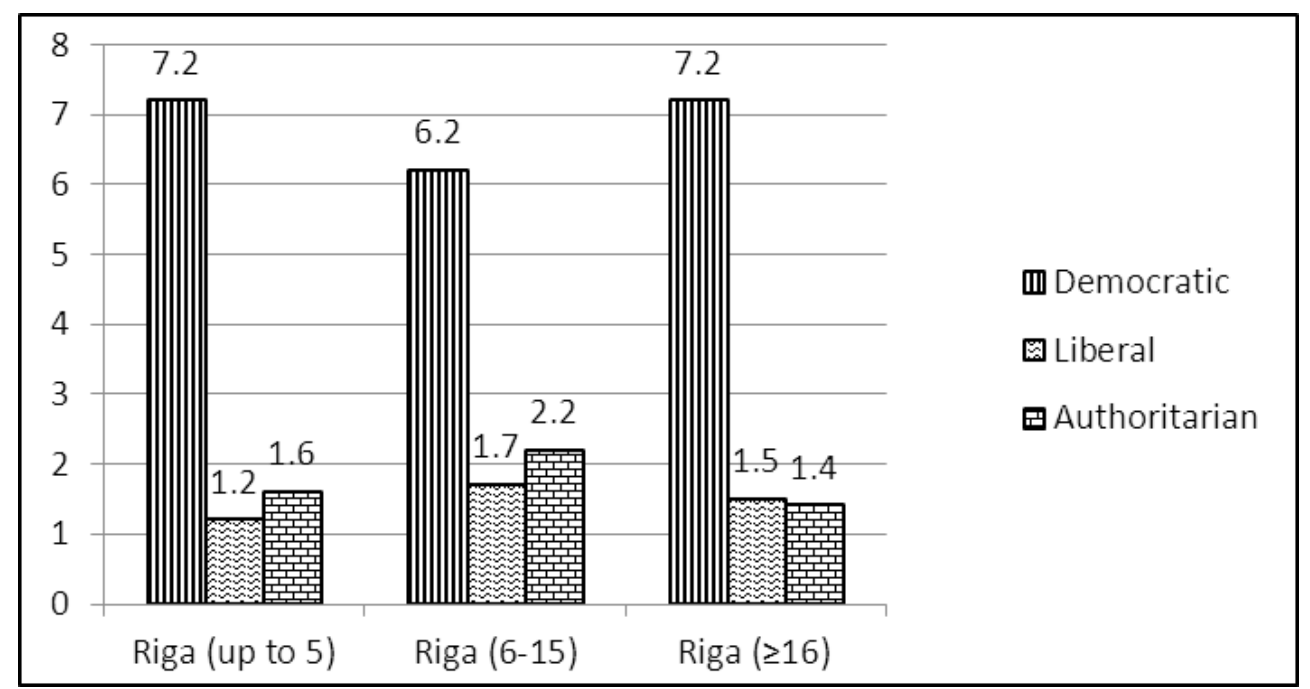

Fig. 2. Teaching style (mean rates). Riga

In both countries, in all age groups, there is good statistical coherence of the responses corresponding to the democratic style of teaching; the coefficient of variation is low enough: from $25 \%$ to $35 \%$. The highest variability was observed in the responses corresponding to the liberal style of teaching: $68-108 \%$. Though the least preferred, this style of teaching provides an opportunity for an individual approach and personally important interrelation between the teacher and the student. The highest variability was noted in the liberal options chosen by young teachers. 


\section{Psycho-emotional state}

The survey showed that both in Russia and in Latvia, school teachers today do not have positive mood and emotional comfort at work. Most of the teachers are emotionally unstable (the corresponding responses demonstrate high statistical reliability and a low level of variability). Great diversity of emotional states is typical for the teaching activities. Therefore, significant prevalence of multiform individual emotional reactions over absolutely positive and hopeless negative reactions seems quite natural. However, half of the 'unstable' answers (from 10 questions defining the emotional state) point to emotional depression, discomfort, inability to control himself (for example, the option 'sometimes' for the statements: 'I miss the warmth and support from my family and colleagues', 'Some of the students make me irritable that is difficult to hide', etc.).

According to teachers' questionnaires, the second more frequent option (after the emotional instability) is the emotional safety; the unfavourable state is the least frequent. This distribution is the same for all the three groups of teachers in both countries (see Figs. 3 and 4), though the results of the Latvian teachers are slightly more positive. For the Smolensk teachers, the following correlation has been found: the longer their teaching experience, the more often they choose the 'unstable' response options; in Riga, no dependence of the emotional instability on the length of service has been observed.

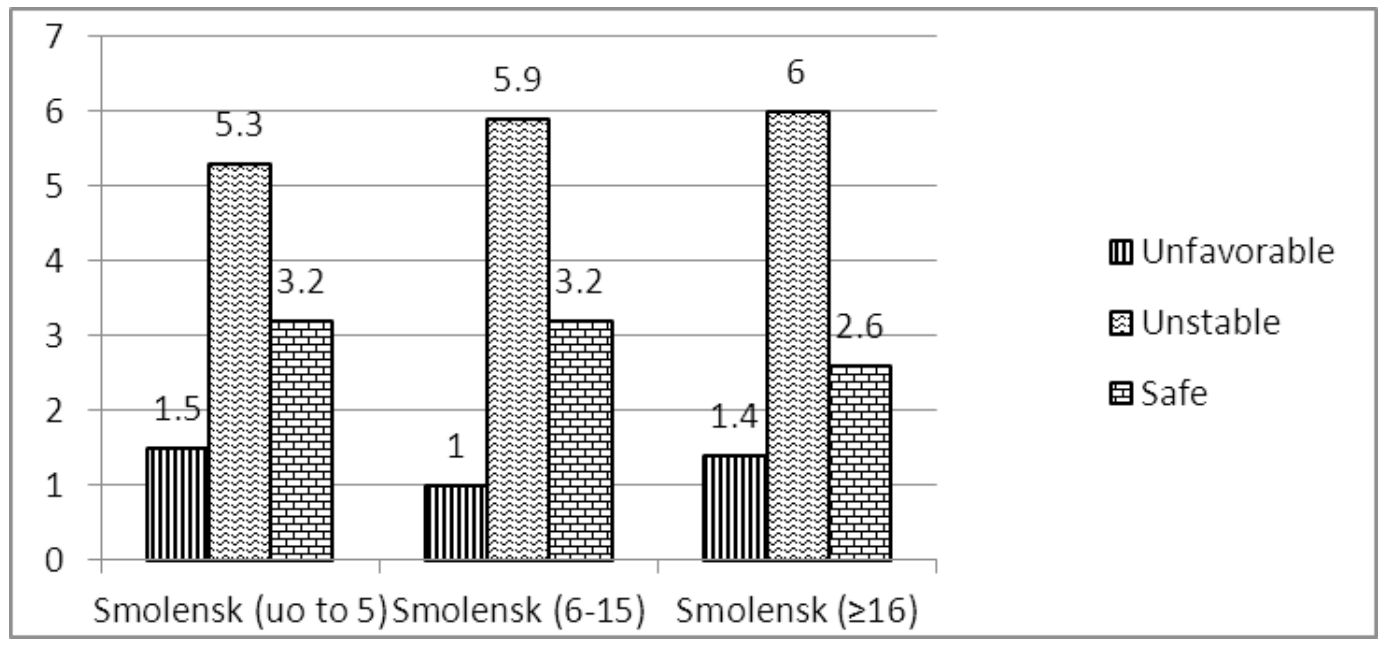

Fig. 3. Psycho-emotional state (mean rates). Smolensk

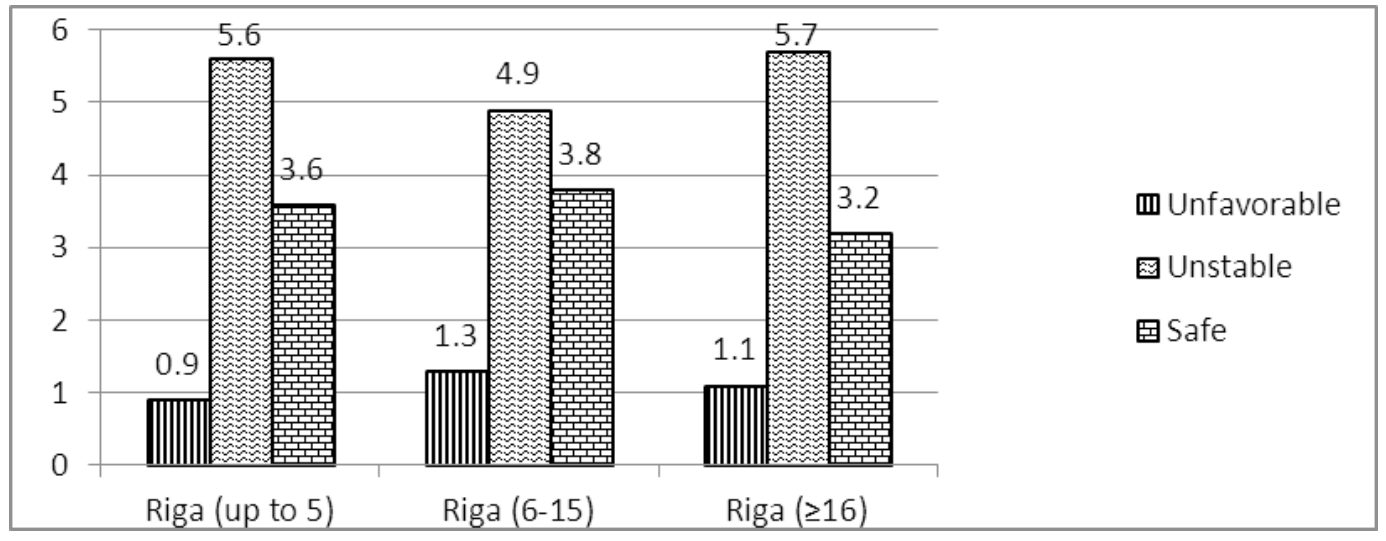

Fig. 4. Psycho-emotional state (mean rates). Riga 
The rates of the emotional safety are not high in either country; however, they exceed the average scores of the unfavourable emotional state. In both Smolensk and Riga, the teachers of the 'older' group showed the lowest rate of the stable emotional safety in the situations presented in the test. This fact can be explained by burnout symptoms accumulated after 15 years of work in school.

The diversity of answers pointing to the unfavourable psycho-emotional state is very high in all the groups of both countries (the variation coefficient is about $100 \%$ or more). This means that occasions and situations that give rise to negative emotional states strongly vary depending on personality of teacher. In Smolensk, young teachers and teachers with long length of service demonstrate the unfavourable emotional state more often than their colleagues from the second group. For the older group, this is another confirmation of the burnout growing over the years of work; in their turn, young teachers lack experience. Therefore some situations seem difficult to resolve to them. In Riga, it is not the case: the teachers of the second group have the maximum score for the unfavourable emotional state; at the same time, in this group, the rate of the emotional safety is the highest, and the score for the emotional instability is the lowest.

\section{Self-evaluation}

Though emotionally instable, most teachers in Latvia and in Russia evaluate themselves positively: they are confident, active and realise the social significance of their work. With the exception of the younger group of Smolensk teachers, the average score of positive self-evaluation is 4 or more; the coefficient of variation points to the suitable coherence of the responses corresponding to this option. The unstable self-evaluation takes the second place; the negative self-evaluation is the rarest. The analysis of the questionnaires shows that the factor that makes teachers doubt in their own abilities most often is the communication with the school administration; more rarely it is communication with colleagues and almost never with the students. As mentioned above, most part of the teachers use the democratic style of teaching, however, they lose selfconfidence under the pressure of hierarchical structures.

Self-evaluation of young Latvian teachers is higher in comparison to their young colleagues from Smolensk. Perhaps this is the result of the efficient system of pedagogical career guidance in Latvia and of purposeful support provided to students of pedagogical universities by their teachers. Comparing the responses of Russian and Latvian teachers, one can also note the difference in the trends of self-evaluation: Russian teachers' long-standing professional activity rather enhances self-evaluation than reduces it, while their Latvian colleagues, even with fairly good overall rates, do not demonstrate this positive growth in self-evaluation. To find out causes of this phenomenon, a more thorough research is required. Probably, experienced teachers feel undervalued by society.

\section{Level of subjective control}

Almost half of the test participants in all age categories gave answers that indicate to the high level of subjective control. Approximately the same number of responses shows that the respondents have not sufficiently formed their internal locus of control; they doubt in their strength and are not sure that their achievements will be recognised by society. The option 'low level of locus of control' receives the lowest scores in this survey (less than 1 for all groups). Complete dependence on circumstances of any kind is not typical for people engaged in professional pedagogical sphere. The active character of pedagogical work, the teacher leading the student from ignorance to knowledge, as well as freedom of choice of teaching means and methods of pedagogical influence, encourage the formation of internal locus of control. 


\section{Priority values in teaching}

The data on this criterion are the least coherent for both countries. The psychological comfort of pupils and the development of their personalities and capabilities, which is the most basic value according to pedagogical textbooks and programme documents, does not seem very important for the teachers. Their own experiences prove to be the priority value in all groups of respondents, except for young Riga teachers. Teacher's unstable position manifested in many options of the test (for example, unstable emotional state, unformed subjective control) makes teachers to care about their own experiences and their place in educational system more than about pupils' well-being in school. The relationship with pupils and colleagues proved to be less important (see Fig. 5, 6). The results shown in the group of young Latvian teachers draw special attention: these data are nearer to the desirable pedagogical ideal than those of other five groups.

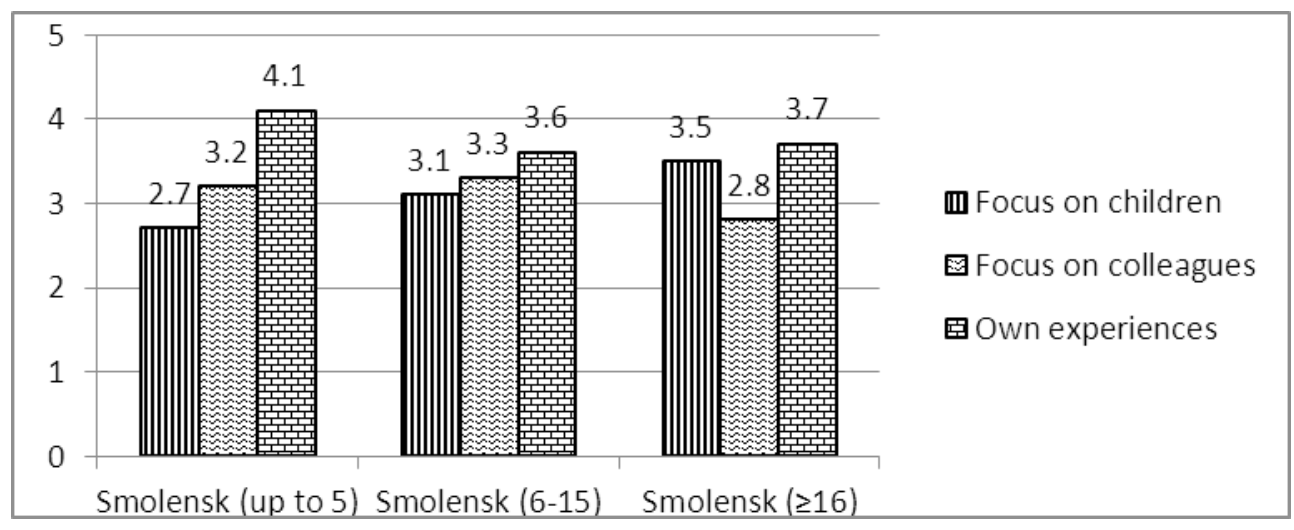

Fig. 5. Priority values (mean rates). Smolensk

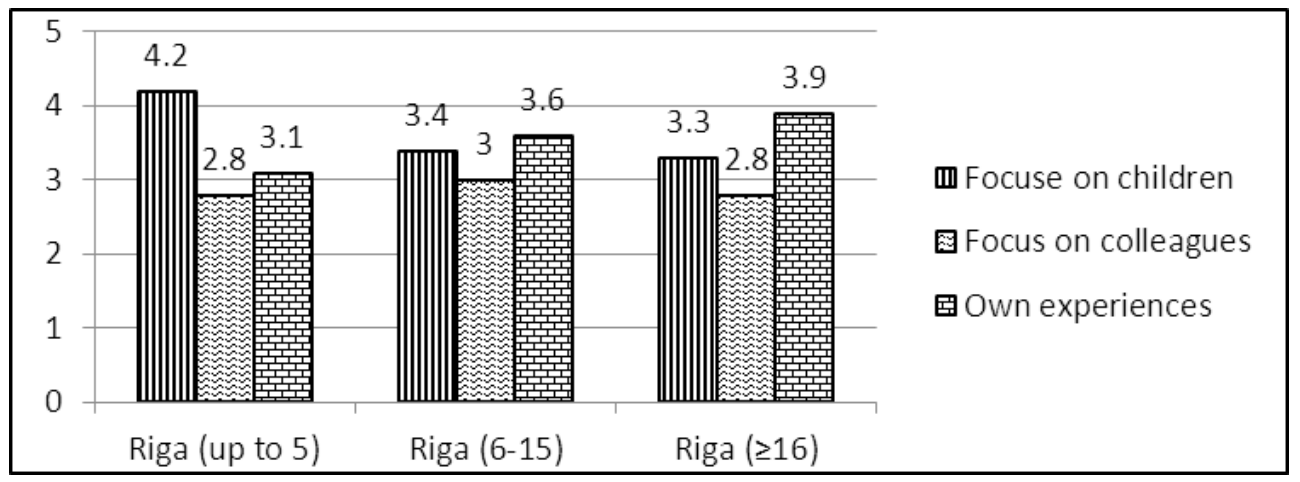

Fig. 6. Priority values (mean rates). Riga

It should be noted that the category 'priority values' has the least reliable statistical mode. The coefficient of variation for all the options (the relationship with children, relationship with colleagues, own experiences) is high enough in all the groups. This means that respondents' reactions vary very much when they choose answers for this category. Therefore, the mode ('own experiences') is not typical or reliable. However, in this case, unreliability gives hope. The modern teacher sometimes might feel disoriented and insecure in the process of reforming not only school but life itself, however he has not lost the main professional values, which are only scattered and mixed with the 'indices of efficiency' of his/her work. 


\section{Conclusions}

Both Russian and Latvian teachers consider the democratic style of teaching the most appropriate and use the liberal and authoritarian forms at least two times rarer. At the same time, the authoritarian style is more preferable for them than the liberal one.

The self-evaluation of Russian and Latvian teachers is mostly positive; the second most common is the unstable one. The teachers of both countries are characterised by high personal responsibility for the results of their work (internal locus of control).

However, there are some facts that require immediate attention of the organisers of the education reform, school headmasters, teacher trainers and the teachers themselves, so that they stand together against the negative tendencies. These facts indicate to an alarming situation in educational systems of both countries. The most frequent option of psycho-emotional state of the teacher is emotional instability connected with the lack of volitional regulation of the emotional sphere and the difference between the affective attitudes of the teacher and his/her actual behaviour.

The data on the category 'priority values in teaching' are particularly alarming: the teachers' own experiences are priority value to the most of them. The relationship with children is the least preferred value in two groups of Russian teachers, though the coefficient of variation for this option is high.

Comparing the questionnaires of Smolensk and Riga teachers, it can be noted that, on the whole, the Latvian teachers are a little ahead of their Russian colleagues in the measured categories: they are slightly more positive and safe, a little less authoritative and a nearer to the desirable pedagogical ideal regarding the priority values. A further study is required to clarify and analyse this result. One possible reason for such a difference between teachers from these countries might be the fact that school reforming in Latvia (democratisation of educational system, introduction of educational standards and centralised examinations, changing the school financing, etc.) began earlier than in Russia and has already given some positive results.

In conclusion, it should be noted that this study is the beginning of a future broader research, which is supposed to include teachers from other European countries, in particular, Lithuanian, Armenian and Ukrainian teachers. This research will contribute to the efficient reform of education in our countries.

\section{References}

Geske, A., Ozola, A. (2014). LATVIA - TALIS. The OECD Teaching and Learning International Survey. Retrieved 22.02.2015. from: http://sf.viaa.gov.lv/library/files/original/TALIS2013_CNote_Latvija_Paplasinats_12Junijs2014.pdf

Jermolajeva, J. (2011). Jauniešu dialog̣iskums/nedialoğiskums viṇu uzvedībā konfliktsituācijās un attieksmē pret ekstrēmistisko darbību. In: A. Špona, V. Sobkin. (Zin. red.) Mūsdienu skolēni Rīgā un Maskavā: Salīdzinošais starptautiskais pētījums [Contemporary school students in Riga and Moscow: International Comparative Research] Rīga: RaKa, Ipp.177-199. (in Latvian)

Priževoite, I. (2013). Pedagogu darba samaksu ietekmējošie faktori vispārējās izglītības iestādēs Latvijā [Factors Influencing Teachers' salaries at Latvian schools]. Rīga: LIZDA. (in Latvian)

Каспржак, А. Г. (2014). Подготовка учителей. Есть ли у России шанс выйти из тупика? [Teacher training. Does Russia have a chance to break the deadlock?] Журнал руководителя управления образованием [Journal of Head of education management], №3, c. 51-63. (in Russian)

Малинецкий, Г.Г., Равлюк, С.Г., Степанцов, М.Е. (2005). Математическое моделирование и прогнозирование динамики возрастной структуры учителей средних школ России [Mathematical modeling and forecasting the dynamics of the age structure of teachers of secondary schools in Russia]. Retrieved 22.02.2015. from: http://www.keldysh.ru/ papers/2005/prep90/prep2005_90.html_(in Russian)

Резапкина, Г.В. (1999). Психологический портрет учителя: опыт самодиагностики [Psychological portrait of a teacher: the experience of self-diagnosis]. Психолог в школе: Ежеквартальный научно-практический журнал [Psychologist at school: Quarterly scientific journal], №2, c. 24-31. (in Russian)

Степанцов, М.Е. (2005). Модель возрастной структуры учителей средней школы [Model for age structure of teachers of secondary school]. Математическое моделирование [Mathematic modeling], №3, c. 61-66. (in Russian) 